\title{
KEPEMIMPINAN PEMBELAJARAN DAN CAPACITY BUILDING DALAM MUTU KINERJA MENGAJAR GURU SD
}

Oleh:

Suryana

SD Negeri 4 Batujajar

(E-mail: suryanaaza205@gmail.com)

\begin{abstract}
ABSTRAK
Peningkatan mutu pendidikan melalui peran kepala sekolah sebagai pemimpin pembelajaran dan pengembangan keprofesian berkelanjutan terhadap kinerja mengajar guru merupakan upaya untuk dilakukan. Penelitian ini bertujuan untuk mendeskripsikan pengaruh peran kepemimpinan pembelajaran kepala sekolah dan pengembangan keprofesian terhadap mutu kinerja guru dengan menggunakan metode survey melalui pendekatan kuantitatif. Hasil temuan dan uji analisis korelasi regresi sederhana dan berganda diharapkan dapat membuktikan hipotesis penelitian ini. Hasil penelitian secara parsial mengenai kepemimpinan pembelajaran dan pengembangan keprofesian berkelanjutan masing-masing memilki hubungan sedang dan searah dengan mutu kinerja mengajar guru. Secara simultan kepemimpinan pembelajaran dan pengembangan keprofesian berkelanjutan berpengaruh sedang terhadap mutu kinerja mengajar guru.
\end{abstract}

Kata kunci : Kinerja mengajar guru, Kepemimpinan pembelajaran, Pengembangan keprofesian berkelanjutan.

\section{ABSTRACT}

Improving the quality of education through the role of school principals as learning leaders and sustainable professional development of teacher teaching performance is an effort to be carried out. This study aims to describe the influence of the principal's leadership learning role and professional development on the quality of teacher performance using a survey method through a quantitative approach. The findings and tests of simple and multiple regression correlation analysis are expected to prove this research hypothesis. Partial research results on leadership learning and sustainable professional development each have a moderate and direct relationship with the quality of teacher teaching performance. Simultaneously leadership learning and sustainable professional development influence the quality of teacher teaching performance.

Keywords: Leadership of learning, Teacher teaching performance, Sustainable profession development

\section{PENDAHULUAN}

Tujuan pendidikan dasar adalah meletakkan dasar kecerdasan, pengetahuan, kepribadian, akhlaq mulia, serta keterampilan untuk hidup mandiri dan mengikuti pendidikan lebih lanjut. Untuk mencapai tujuan tersebut diperlukan berbagai upaya melalui langkahlangkah yang sesuai dengan tujuan yang diharapkan. Dalam konteks pemecahan masalah dan pencapaian tujuan, maka langkah -langkah itu harus dimulai dari konteks input, proses, output dan berakhir dengan outcome (Hamzah. 2011). Input pendidikan terdiri dari tenaga pengajar(guru), siswa, kurikulum, sarana prasarana, lingkungan, biaya pendidikan, peran masyrakat dan input-input lainnya, sedangkan "proses pendidikan adalah suatu pelaksanaan atau kejadian yang terjadi secara alami atau didesain dengan sengaja" (Mulyasa, 2012), melalui profesionalisme para pelaku pendidikan harus mampu untuk tanggap dan mencernanya dengan mendesain secara interaktif dan sederhana. Proses pendidikan terdiri dari proses pengelolaan lembaga, proses pengelolaan program, proses pembelajaran, proses pengambilan keputusan, proses monitoring, dan evaluasi. Output adalah hasil atau keluaran akademik dan non akademik yaitu prestasi siswa yang memilki kompetensi yang disyaratkan, Outcome pendidikan adalah hasil pada jangka panjang terhadap lulusan yang mampu melanjutkan ke jenjang yang lebih tinggi, dapat terserap oleh dunia kerja dan mampu mengembangkan dirinya.

Tenaga pengajar (Guru) merupakan salah satu input pendidikan hendaknya memahami, 
menguasai dan mampu melaksnakan kegiatankegiatan yang berkenaan dengan tugas utamanya yang telah diatur dalam Peraturan Menteri Pendayaan Aparatur Negara dan Revormasi Birokrasi Nomor 16 Tahun 2009 Pasal 1 bahwa "Tugas utama guru adalah mendidik, mengajar, membimbing, mengarahkan, melatih, menilai, dan mengevaluasi peserta didik pada pendidikan usia dini, jalur pendidikan formal, pendidikan dasar, dan menengah serta tugas tambahan yang relevan dengan dengan fungsi sekolah/Madrasah”.

Aspek kualitas pembelajaran adalah kemampuan guru dalam menyampaikan pembelajaran agar mudah dipahami dan diingat sejalan dengan Implementasi Undang-Undang Nomor 20 Tahun 2003 Tentang Sistem Penidikan Nasional pasal 40 ayat 2a, yaitu pendidik berkewajiban menciptakan suasana pendidikan yang bermakna, kreatif, dinamis, dan dialogis yang dikenal dengan istilah PAIKEM (pembelajaran aktif, inovatif, kreatif, efektif dan menyenangkan). (Supardi, 2013).

Rahman dkk (2005) kinerja mengajar guru merupakan seperangkat perilaku nyata ditunjukkan guru pada waktu dia memberikan pelajaran kepada siswanya. Guru sebagai perencana, seharusnya mampu menganalisis kebutuhan peserta didik untuk dapat menerima pelajaran dengan memilih dan menguasai bahan ajar, menentukan metode dan pendekatan pembelajaran, mengembangkan silabus, menyusun program tahunan atau semester, dan menyusun rencana pelaksanaan pembelajaran (RPP). Sebagai pelaksana pembelajaran, guru harus mampu melakukan kegiatan membuka atau menutup kegiatan pembelajaran, mampu mengelola kelas, menggunakan media dan sumber belajar dengan baik, menggunakan metode belajar, serta mampu menggunakan berbagai macam strategi belajar. Pada saat melakukan kegiatan evaluasi, guru hendaknya mampu menentukan pendekatan dan cara-cara evaluasi, menyusun alatalat evaluasi, mengolah dan menganalisis hasil evaluasi, dan menggunakan hasil evaluasi untuk mengukur sejauh mana ketercapaian keberhasilan kegiatan belajar yang ditempuh peserta didik dalam proses belajar.

Dalam proses belajar mengajar, guru perlu membuat perencanaan agar dalam pelaksanaan pembelajaran dapat berlangsung dengan baik dan mencapai hasil yang diharapkan. Setiap perencanaan selalu berkenaan dengan pemikiran tentang apa yang akan dilakukan. Perencanaan program belajar mengajar memperkirakan mengenai tindakan apa yang akan dilakukan pada waktu melaksanakan pembelajaran.

Berdasarkan studi pendahuluan wawancara dengan beberapa guru dan kepala sekolah dan hasil observasi, diperoleh kesimpulan bahwa mutu kinerja mengajar guru SD Negeri Di Kecamatan Batujajar belum optimal.

Berdasarkan kondisi tersebut, penulis perlu mencermati bermutunya kinerja mengajar guru disebabkan oleh faktor-fakator yang mengaruhi ketercapaian mutu kinerja mngajar guru.

Salah satu faktor yang mempengaruhi mutu kinerja mengajar guru adalah kepemimpinan pembelajaran kepala sekolah. Hasil Penelitian Stronge (dalam Daryanto, 2011) menunjukkan bahwa seluruh pekerjaan yang harus dilaksanakan kepala sekolah, hanya $10 \%$ yang dialokasikan untuk kepemimpinan pembelajaran. Kepala sekolah dituntut melaksanakan perannya yang seimbang agar tidak terjadi ketimpangan dan keterbengkalaian. "Banyak penelitian yang menyimpulkan bahwa kepala sekolah yang memfokuskan kepada kepemimpinan pembelajaran menghasilkan prestasi belajar siswa yang lebih baik dari pada kepala sekolah yang kurang memfokuskan pada kepemimpinan 
pembelajaran. Ironisnya, kebanyakan kepala sekolah tidak menerapkan model kepemimpinan pembelajaran" (Kepala Badan Pengembangan Sumber Daya Manusia Pendidikan dan Penjaminan Mutu Pendidikan, 2010; 3).

Kepemimipinan pembelajaran merupakan aktivitas kepala sekolah yang kesehariannya disibukkan dengan kegiatan mempengaruhi orangorang yang menjalankan kegiatan akademik di sekolah, mereka adalah guru dan staf edukatif atau staf teaching. Kesibukan utamanya berhubungan dengan guru, baik secara perorangan maupun kelompok untuk memperbaiki dan meningkatkan kegiatan akademik, yaitu meningkatkan situasi belajar mengajar. (Suhardan, 2014)

Dengan kegiatan mempengaruhi orangorang yang menjalankan kegiatan akademik di sekolah, maka terjadi adanya perhatian dari seorang pemimpin pembelajaran. Soutworth menyatakan bahwa kepemimpinan pembelajaran adalah perhatian yang kuat terhadap pengajaran dan pembelajaran termasuk pembelajaran professional oleh guru sesuai perkembangan siswa (Soutworth, G. 2002)

Ketika seorang pemimpin pembelajaran mempengaruhi, memperhatikan, perlu adanya tindakan dalam arti "kepemimpinan pembelajaran sebagai suatu tindakan yang dilakukan kepala sekolah dengan maksud mengembangkan lingkungan kerja yang produktif dan memuaskan bagi guru, serta pada akhirnya mampu menciptakan kondisi belajar siswa meningkat (McEwan E.K, 2002).

Dalam melakukan tindakan pengembangan, baik secara langsung maupun secara tidak lansung, haruslah berdasarkan arah pada kemajuan, seperti yang dikemukakan Ubben dan Hughes (1992) bahwa "pemimpin pembelajaran merupakan tindakan pada pembelajaran langsung (direct intructional) maupun tidak langsung (indirect instructional) yang mengarah pada upaya peningkatan kemajuan belajar anak didik (Ubben, G.C., \& Hughes, L.W. 1992)

Dengan kegiatan memahami bagaimana untuk mempengaruhi, memperhatikan dan melakukan tindakan, Peranan kepemimpinan (instruction-nal leadership) dalam meningkatkan profesionalisme guru sudah lama diakui sebagai suatu faktor penting dalam organisasi sekolah, terutama terkait dengan tanggungjawab dalam meningkatkan kualitas pembelajaran di sekolah (Gorton, 1991: Halinger\& Leitwood, 1994). Atas dasar motif utamanya untuk meningkatkan: 1) Keterampilan Guru, (2) pelaksanaan kurikulum,(3) struktur organisasi, dan (4) kerja sama sekolah dengan orang tua siswa dan masyarakat(Ubben dan Huhes, 1992).

Menurut Bafadal (2016) memaparkan pengalamannya sebagai Direktur Pembinaan SD Kemdikbud, ketika melakukan uji kompetensi kepala sekolah pada tahun 2015-2016, dari 856 kepala sekolah dari seluruh wilayah Indonesia hanya ditemukan 16\% kepala sekolah yang melaksanakan perannya sebagai kepemimpinan pembelajaran, selebihnya banyak yang menjalankan peran lain, seperti manajer sekolah atau mengurusi masalah administrasi dan sarana prasarana pendidikan.

Faktor lain yang mempengaruhi mutu kinerja guru adalah kemampuan guru itu sendiri sebagai tenaga profesional. Masih belum maksimalnya profesional terhadap tugas utama guru yang disyaratkan terhadap mutu kinerja mengajar guru berdasarkan publikasi dokumentasi Kemendikbud Tahun 2015-2016 baru mencapai 60,19 dengan kategori cukup. Memahami akan tugas, beban kerja dengan aspek kualitas yang disyaratkan yang diperlihatkan melalui pelaksanaan tugas atau pekerjaannya. Mutu 
kinerja mengajar guru yang berkualitas merupakan kunci bermutunya pendidikan karena guru adalah pihak yang bersentuhan langsung dengan proses pembelajaran.

Selain itu, faktor yang mempengaruhi mutu kinerja mengajar guru adalah adanya capacity building yang diberikan terhadap guru. Masih belum maksimalnya Capacity Building sebagai bentuk pembinaan profesional terhadap tugas utama guru yang disyaratkan terhadap mutu kinerja mengajar guru berdasarkan publikasi dokumentasi

Capacity Building merupakan sebuah pengembangan yang akan menuntut kegiatan sebuah organisasi mencapai tujuannya hal tersebut seperti yang dijelaskan CIDA (Matachi, 2006:21) yang mengatakan bahwa "Capacity Building is a process by which individuals, groups, institutions, organizations and societies enhance their abilities to identify and meet development challenges in a sustainable manner". Maksud dari pernyataan ini merupakan pengertian dari pengembangan kapasitas yang dapat diartikan sebaga proses untuk meningkatkan kemampuan individu, organisasi, da sebuah institusi untuk meningkatkan kemampuan dalam menghadapi tantangan yang berkelanjutan.

Penerapan Capaity Building pada tingkat individu merupakan bagian yang di dalamnya terdapat peningkatan pengetahuan dengan cara mengikuti seminar, pelatihan, workshop, dan kegiatan lainnya yang sejenis. Dalam tingkat individu juga penerapannya dapat berupa pengembangan pada kemampuan guru dakam kinerja mengajar. Bagi tingkat organisasi pengembangan lebih berfokus pada kemampuan seluruh guru pada satuan pendidikan tertentu dalam kemampuan merencanakan dan mengelola pembelajaran, implementasi keahlian yang dimiliki setiap guru, dan kemampuan menggunakan fasilitas dan mempersiapkan media pembelajaran dalam menunjang kinerja mengajar guru
Kemendikbud Tahun 2015-2016 baru mencapai 60,19 dengan kategori cukup. Penilaian terhadap kinerja mengajar guru sebagai tolak ukur. Berdasarkan data publikasi dari Kemendikbud, Kinerja guru SD Negeri termasuk kurang dengan nilai 60.19. Bila dilihat dari kinerja guru yang tak lepas dari bagaimana kepemimpinan kepala sekolah bahwa kinerja SDM Dikdasmen secara keseluruhan termasuk katagori kurang, sebesar 77,69 , bila dirinci menurut status sekolah maka SD termasuk kategori kurang. Data Rekapitulasi RataRata Nilai UKG SD Negeridi Kabupaten Bandung Barat Tahun 2015 - 2016 di atas, secara keseluruhan rata-rata nilai UKG Kabupaten Bandung Barat 56,6. Sementara nilai rata-rata UKG Kecamatan Batujajar 57,02. Maka untuk tingkat kabapaten, Kecamatan Batujajar sudah memadai, akan tetapi Jika dibandingkan dengan Kecamatan Padalarang, Lembang, Cipatat, dan ngamprah, maka Kecamatan Batujajar masih berada dibawahnya, apalagi dengan data publikasi dari Kemendikbud kinerja Dikdasmen 60.19, maka nilai rata-rata UKG Kecamatan Batujajar belum sampainya terhadap nilai yang telah dipublikasikan oleh Kemendikbud, artinya masih diperlukan pengembangan kinerja mengajar guru agar lebih optimal diantaranya melalui Pengembangan Keprofesian Berkelanjutan (PKB). karier sesuai dengan tuntutan pengembangan kualitas".

Berdasarkan uraian diatas, maka penelitian ini bertujuan untuk: (1) mendeskripsikan mutu kinerja mengajar guru; (2) kepemimpinan pembelajaran kepala sekolah; (3) pengembangan keprofesian berkelanjutan guru; (4) hubungan kepemimpinan pembelajaran kepala sekolah dengan mutu kinerja mengajar guru; (5) hubungan pengembangan keprofesian berkelanjutan terhadap mutu kinerja mengajar guru; (6) pengaruh kepemimpinan pembelajaran kepala sekolah dan 


\section{METODE PENELITIAN}

Penelitian ini menggunakan pendekatan kuantitatif dengan metode survey deskriptif. Metode survey deskriptif kuantitatif merupakan suatu metode penelitian yang mengambil sampel dari suatu populasi dan menggunakan kuesioner sebagai alat pengumpulan data. Penelitian deskriptif yaitu desain penelitian yang disusun dalam rangka memberikan gambaran secara sistematis tentang informasi ilmiah yang berasal dari subjek atau objek penelitian (Sandu, 2015; Purwanto, 2011).

Varibel dalam penelitian ini adalah kepemimpinan pembelajar kepala sekolah (X1), pengembangan Keprofesian Berkelanjutan (X2) dan Kinerja Guru (Y). mutu kinerja guru dalam penelitian ini dilihat dari dimensi reabilitas, daya tanggap, jaminan, empati, bukti fisik. Adapun kepemimpinan pembelajaran dilihat dari Peningkatan secara berkelanjutan, Kultur pembelajaran, Penilaian hasil belajar, Pengembangan profesionalisme guru, Manajemen sekolah dan perbedaan. Sedangkan dimensi pengembangan keprofesian berkelanjutan terdiri atas Dilakukan oleh guru sendiri, Bekerja sama dengan guru dalam satu sekolah, melalui jaringan dan kepakaran.

Adapun desain penelitian ini dapat dilihat pada gambar berikut.

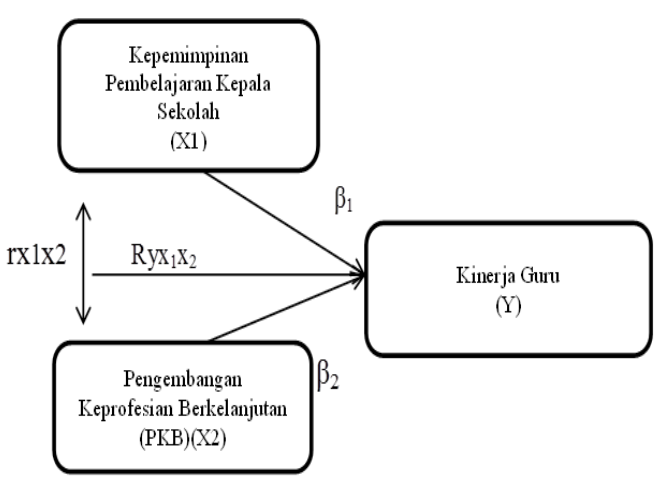

Gambar 1

Desain Penelitian

Populasi yang dijadikan objek penelitian ini adalah seluruh guru kelas 6 SD negeri Di Kecamatan Batujajar Kabupaten Bandung Barat yang berjumlah 38 orang dan seluruh siswa kelas 6 yang berjumlah 1507 siswa. Penentuan jumlah sampel menggunakan teknik Probability Sampling. Sampel penelitian berjumlah 28 orang guru dan 94 siswa.

Penelitian ini menggunakan angket sebagai alat untuk pengumpulan data penelitian. Sebelum angket disebarkan, dilakukan uji validitas dan reliabilitasnya.

Analisis data penelitian dilakukan melalui editing terhadap data yng terkumpul, tabulasi data. Teknik analisis data yang digunakan adalah analisis regresi berganda dengan menggunakan program SPSS (Statistical Package for Social Science) versi 22.

\section{HASIL PENELITIAN}

Berdasarkan temuan penelitian dari data, hasil analisis korelasi dan regresi yang sederhana dan berganda mengenai peranan kepemimpinan pembelajaran dan pengembangan keprofesian berkelanjutan terhadap mutu kinerja mengajar guru secara khusus hasil pengujian hipotesis menjawab rumusan masalah penelitian ini, dengan menunjukkan bahwa:

\section{Hasil Temuan Gambaran Variabel Penelitian}

a. Hasil Temuan Gambaran Mutu Kinerja Mengajar Guru 
Gambaran mutu kinerja mengajar guru SD di Kecamatan Batujajar Kabupaten Bandung Barat, sebagai variabel Y secara umum berkriteria baik dengan rata-rata prosentase benar dari setiap dimensi adalah 65,8\% sedangkan dimensi paling rendah adalah $63,4 \%$, jika di rata-ratakan jawaban responden dari total seluruh pernyataan adalah berada pada nilai $1,92 \%$. Hal ini berarti bahwa dari jawaban 33 pernyataan mutu kinerja mengajar guru yang diberikan kepada guru rata-rata guru menjawab soalnya adalah tinggi dengan nilai rata-rata 3,29 .

b. Hasil Temuan Gambaran Kepemimpinan Pembelajaran

Gambaran kepemimpinan pembelajaran kepala sekolah sebagai variabel $\mathrm{X}_{1}$, berdasarkan kuisiner pada guru-guru sebagai sampel penelitian, didapat: 1) secara umum berkriteria baik dengan rata-rata prosentase benar dari setiap dimensi adalah $60,3 \%$ sedangkan dimensi paling rendah adalah 58,6\%. jika di rata-ratakan jawaban responden dari total seluruh pernyataan adalah berada pada nilai $1,77 \%$. Hal ini berarti bahwa dari jawaban 34 pernyataan kepemimpinan pembelajaran yang diberikan kepada guru rata-rata guru menjawab soalnya adalah tinggi dengan nilai rata-rata 3,62 .

c. Hasil Temuan Gambaran Pengembangan Keprofesian Berkelanjutan

Gambaran pengembangan keprofesian berkelanjutan pada guru SD di Kecamatan Batujajar Kabupaten Bandung Barat, sebagai variabel X2 secara umum berkriteria baik dengan rata-rata prosentase benar dari setiap dimensi adalah $87,75 \%$ sedangkan dimensi paling rendah adalah $85 \%$, jika di rata-ratakan jawaban responden dari total seluruh pernyataan adalah berada pada nilai $2,6 \%$. Hal ini berarti bahwa dari jawaban 34 pernyataan pengembangan keprofesian berkelanjutan yang diberikan kepada guru rata-rata guru menjawab soalnya adalah tinggi dengan nilai rata-rata 3,51 .

\section{Hasil Analisis Uji Data}

a. Kepemimpinan Pembelajaran dan mutu kinerja mengajar memiliki kekuatan hubungan yang sedang dengan signifikansi linearity sebesar 0,02 yaitu lebih kecil dari nilai kritis $(0,05)$, dan nilai koefisien Pearson Correlation yaitu sebesar 0,413. Hipotesis diterima yang ditandai dengan lebih kecilnya nilai signfikansi dari nilai kritis $(0,036<0,05)$ sedangkan besarnya $\mathrm{R}$ Square 0,171 , maka besarnya pengaruh kepemimpinan pembelajaran terhadap mutu kinerja mengajar $17,1 \%$ dan sisanya $82,9 \%$ dipengaruhi oleh faktor lain yang tidak diteliti dalam penelitian ini.

b. Pengembangan Keprofesian Berkelanjutan dengan mutu kinerja mengajar memiliki kekuatan hubungan yang sedang dengan signifikansi linearity sebesar 0,000 yaitu lebih kecil dari nilai kritis $(0,05)$, dan nilai koefisien Pearson Correlation yaitu sebesar 0,588 . Hipotesis diterima yang ditandai dengan lebih kecilnya nilai signfikansi dari nilai kritis $(0,001<0,05)$ sedangkan besarnya $\mathrm{R}$ Square 0,346 , maka besarnya pengaruh kepemimpinan pembelajaran terhadap mutu kinerja mengajar $34,6 \%$ dan sisanya $65,4 \%$ dipengaruhi oleh faktor lain yang tidak diteliti dalam penelitian ini. 
c. Kepemimpinan Pembelajaran dan Pengembangan Keprofesian Berkelanjutan dengan mutu kinerja mengajar memiliki kekuatan hubungan yang yang sedang, dengan nilai koefisien Pearson Correlation 0,384 , Hipotesis diterima yang ditandai dengan lebih kecilnya nilai signfikansi dari nilai kritis $(0,000<0,05)$, sedangkan besarnya $\mathrm{R}$ Square 0,349 , maka besarnya pengaruh Kepemimpinan Pembelajaran dan Pengembangan Keprofesian Berkelanjutan terhadap mutu kinerja mengajar 38,4\% dan sisanya $61,6 \%$ dipengaruhi oleh faktor lain yang tidak diteliti dalam penelitian ini.

Berdasarkan temuan penelitian dari data, hasil analisis korelasi dan regresi yang sederhana dan berganda mengenai peranan kepemimpinan pembelajaran dan pengembangan keprofesian berkelanjutan terhadap mutu kinerja mengajar guru secara khusus hasil pengujian hipotesis menjawab rumusan masalah penelitian ini, dengan menunjukkan bahwa:

\section{Hasil Temuan Gambaran Variabel Penelitian}

Gambaran mutu kinerja mengajar guru SD Negeri Di Kecamatan Batujajar Kabupaten Bandung Barat.

Gambaran mutu kinerja mengajar guru SD

di Kecamatan Batujajar Kabupaten Bandung Barat, sebagai variabel $\mathrm{Y}$ secara umum berkriteria baik dengan rata-rata prosentase benar dari setiap dimensi adalah $65,8 \%$ sedangkan dimensi paling rendah adalah $63,4 \%$, jika di rata-ratakan jawaban responden dari total seluruh pernyataan adalah berada pada nilai $1,92 \%$. Hal ini berarti bahwa dari jawaban 33 pernyataan mutu kinerja mengajar guru yang diberikan kepada guru rata-rata guru menjawab soalnya adalah tinggi dengan nilai ratarata 3,29 .

Berdasarkan uraian data hasil temuan diatas, secara umum mutu kinerja mengajar guru
SD Negeri Di Kecamatan Batujajar Kabupaten Bandung Barat sudah tergolong baik. Urutan pertama berdasarkan skor tertinggi dalam perolehan jawaban pada dimensi Daya tanggap (responsiveness) sedangkan bukti fisik (tangibles) berada pada urutan kelima sebagai skor terendah akan tetapi masih tergolong baik. Hal ini menunjukkan kemampuan guru dalam memanfaatkan peralatan/bahan ajar, menarik minat siswa belajar melalui penampilannya dalam proses pembelajaran dirasakan oleh siswa belum sepenuhnya memenuhi harapan secara profesional.

Indikator tertinggi sebesar 3.48 pada dimensi Empati (Empaty) dalam mutu kinerja mengajar guru adalah memahaminya akan kebutuhan setiap siswa, sedangkan indikator terendah sebesar 2.92 karena masih belum optimalnya kemampuan guru dalam memberikan pelayanan yang memuaskan.

Rendahnya perolehan skor dimensi bukti fisik (tangibles) penyebabnya dalam kemampuan guru memanfaatkan peralatan/bahan ajar dan menarik minat siswa dalam belajar melalui penampilannya dalam proses pembelajaran, hal itu menyebabkan faktor kebosanan pada siswa. Menurut Hasibuan dan Moedjiono (2006, hlm. 64), faktor kebosanan pada siswa disebabkan oleh adanya penyajian kegiatan belajar yang begitubegitu saja akan mengakibatkan perhatian, motivasi dan minat siswa terhadap pelajaran, guru dan sekolah menurun.

Kemampuan guru dalam kesiapan memberikan layanan dan bantuan kepada siswa dengan cepat diukur dengan tindakan pelayanan yang tepat, profesionalisme dalam menangani keluhan siswa, melayani siswa dengan baik dan ramah, memberikan layanan belajar sesuai dengan tujuan pembelajaran yang telah ditetapkan, dan memberikan pelayanan selalu sesuai dengan 
jadwal dan tepat waktu. Daya tanggap (responsiveness) Menurut Rambat Lupiyoadi (2001:148) daya tanggap adalah "suatu kemauan untuk membantu dan memberikan pelayanan yang cepat (responsif) dan tepat kepada pelanggan, dengan penyampaian informasi yang jelas.

Intinya adalah ketika guru melaksanakan proses pembelajaran diharapkan untuk meningkatkan persiapan dalam (1) membahas materi pelajaran menyampaikan pertanyaan terlebih dahulu mengenai pelajaran yang lalu;(2) sebelum membahas materi pelajaran menyampaikan tujuan pelajaran yang ingin dicapai;(3) dalam menjelaskan materi pelajaran melihat pada buku yang berkaitan dengan materi;(4) dalam menjelaskan materi pelajaran menggunakan bahasa yang jelas sehingga mudah dimengerti;(5) dalam kegiatan mengajar menggunakan cara bervariasi seperti tanya jawab, kuis, diskusi, ceramah dan lain sebagainya;(6) dalam setiap pelajaran berlangsung menggunakan alat bantu belajar baik berdimensi dua ataupun berdimensi 3, seperti karton bergambar, Foto, film, dan fatung, relief gambar dan sebagainya untuk menarik minat belajar siswa.

\section{Gambaran Kepemimpinan pembelajaran kepala sekolah SD Negeri Di Kecamatan Batujajar Kabupaten Bandung Barat berkriteria tinggi dengan penafsiran baik.}

Gambaran kepemimpinan pembelajaran

kepala sekolah sebagai variabel $\mathrm{X}_{1}$, berdasarkan kuisiner pada guru-guru sebagai sampel penelitian, didapat: 1) secara umum berkriteria baik dengan rata-rata prosentase benar dari setiap dimensi adalah $60,3 \%$ sedangkan dimensi paling rendah adalah 58,6\%. jika di rata-ratakan jawaban responden dari total seluruh pernyataan adalah berada pada nilai $1,77 \%$. Hal ini berarti bahwa dari jawaban 34 pernyataan kepemimpinan pembelajaran yang diberikan kepada guru rata-rata guru menjawab soalnya adalah tinggi dengan nilai rata-rata 3,62.

Berdasarkan uraian data hasil temuan diatas, secara umum kepemimpinan pembeljaran kepala sekolah SD Negeri Di Kecamatan Batujajar Kabupaten Bandung Barat sudah tergolong baik. Urutan pertama berdasarkan Skor tertinggi dalam perolehan jawaban pada dimensi peningkatan secara berkelanjutan, kriteria tinggi dan penafsiran baik sedangkan kultur pembelajaran berada pada urutan keenam sebagai skor terendah akan tetapi masih tergolong baik. Hal ini menunjukkan bahwa peranan kepala sekolah sebagai pemimpin pembelajaran dalam membimbing pengembangan proses belajar mengajar melalui penerapan kepemimpinan visioner dan situasional terhadap guru masih kurang dirasakan.

Indikator tertinggi sebesar 4.00 pada dimensi peningkatan secara berkelanjutan adalah pengaruh kepemimpinan pembelajaran dalam merumuskan dan mengartikulasikan tujuan pembelajaran, sedangkan indikator terendah sebesar 3,29 karena masih belum optimalnya kepala sekolah sebagai kepemimpinan pembelajaran dalam menerapkan kepemimpinan visioner dan situasional.

Rendahnya perolehan skor dimensi kultur pembelajaran penyebabnya adalah belum optimalnya kepemimpinan kepala sekolah dalam membimbing pengembangan proses belajar mengajar melalui penerapan kepemimpinan visioner dan situasional terhadap guru, yang diantaranya belum melaksanakan secara optimal dalam mengevaluasi secara periodik mengevaluasi kinerja guru untuk mengetahui berbagai kekuatan dan kelemahan yang dijadikan sebagai bahan untuk melaksanakan pengembangan keprofesian guru.

Kepemimpinan yang kerja pokoknya difokuskan pada rekayasa yang penuh tantangan. 
Kemudian pada gilirannya pemimpin tersebut dapat menjadi agen perubahan yang unggul dan menjadi penentu arah organisasi yang memahami prioritas, menjadi pelatih yang profesional, serta dapat membimbing personel lainnya kearah profesionalisme kerja yang diharapkan (Komariah dan Cepi Triatna, 2005). Sedangkan pemimpinan kultural menurut Ubben\&Hughes (dalam Sergiovanni, 1991). Dalam memainkan perannya sebagai pemimpin kultural, kepala sekolah mengidentifikasi diri dengan kekuatan nilai-nilai (values) dan keyakinan-keyakinan (beliefs) tentang sekolah yang membuat sekolah menjadi unik. Pemimpin kultural berusaha membangun tradisitradisi sekitar sekolah menjadi lebih bernilai tinggi. Ia bertukar pikiran dengan orang lain tentang apa yang lebih bernilai di sekolah dengan menceritakan sejarah keberhasilan sekolah di masa lalu untuk menguatkan tradisi-tradisi tersebut.

Sebagai pemimpin pembelajaran, kepala sekolah diharapkan dapat memainkan peranan penting dalam membangun realitas ini, di antaranya adalah mengartikulasikan tujuan dan misi sekolah, mensosialisasikan staf baru di sekolah, memelihara tradisi-tradisi sekolah yang bernilai tinggi, mengembangkan dan memainkan sistem simbol-simbol, serta memberikan penghargaan terhadap siapa saja warga sekolah yang mampu merefleksikan kultur sekolah pada pelaksanaan tugasnya di sekolah.

\section{Gambaran Pengembangan keprofesian berkelanjutan guru SD Negeri Di Kecamatan Batujajar Kabupaten Bandung Barat berkriteria tinggi dengan penafsiran baik.}

Gambaran pengembangan keprofesian berkelanjutan pada guru SD di Kecamatan Batujajar Kabupaten Bandung Barat, sebagai variabel X2 secara umum berkriteria baik dengan rata-rata prosentase benar dari setiap dimensi adalah $87,75 \%$ sedangkan dimensi paling rendah adalah $85 \%$, jika di rata-ratakan jawaban responden dari total seluruh pernyataan adalah berada pada nilai 2,6\%. Hal ini berarti bahwa dari jawaban 34 pernyataan pengembangan keprofesian berkelanjutan yang diberikan kepada guru rata-rata guru menjawab soalnya adalah tinggi dengan nilai rata-rata 3,51

Berdasarkan uraian data hasil temuan diatas, secara umum pengembangan keprofesian berkelanjutan terhadap guru SD Negeri Di Kecamatan Batujajar Kabupaten Bandung Barat sudah tergolong baik. Urutan pertama berdasarkan Skor tertinggi dalam perolehan jawaban pada dimensi Jaringan sekolah berkriteria tinggi dan penafsiran baik sedangkan Kepakaran luar berada pada urutan keempat sebagai skor terendah akan tetapi masih tergolong baik. Hal ini menunjukkan belum maksimal pemberdayaan terpenuhinya untuk pengembangan keprofesionalan yang lebih lanjut melalui PKG dan dengan mengundang sumber PKB baik para pengawas, LPMP, P4TK maupun dari perguruan tinggi atau institusi layanan lain yang diakui oleh pemerintah.

Indikator tertinggi sebesar 4.05 pada dimensi dilakukan oleh guru sendiri, antara lain mengembangkan kurikulum yang mencakup topiktopik aktual/terkini yang berkaitan dengan sains dan teknologi, sosial, dsb, sesuai dengan kebutuhan peserta didik, sedangkan pada dimensi kepakaran luar indikator terendah sebesar 3,29 karena masih belum optimalnya pengembangan keprofesian berkelanjutan melalui pendidikan dan pelatihan jarak jauh melalui jejaring virtual atau TIK yang diselenggarakan oleh institusi layanan luar negeri.

Rendahnya perolehan skor dimensi kepakaran luar penyebabnya adalah belum optimalnya pengembangan lebih lanjut melalui dengan mengundang sumber PKB baik para 
pengawas, LPMP, P4TK, maupun dari perguruan tinggi atau institusi layanan lain yang diakui oleh sehingga Program kegiatan pengembangan keprofesian berkelanjutan (PKB) yang merupakan amanat dari undang-undang untuk melaksanakan Program kegiatan pengembangan keprofesian berkelanjutan (PKB) yang bertujuan untuk meningkatkan kompetensi guru sebagai agen perubahan dan sumber belajar utama bagi peserta didik dan diharapakan dapat memberikan sumbangan yang sangat besar dalam peningkatan kualitas kompetensi guru.

PKG yang merupakan gabungan dari beberapa KKG mengundang sumber PKB dari LPMP dan atau P4TK. Menurut Surya (2003) Kompetensi profesional guru meliputi kepakaran atau keahlian dalam bidangnya yaitu penguasaan bahan yang harus diajarkan beserta metodenya, rasa tanggung jawab akan tugas, dan rasa kebersamaan dengan sejawat guru lainnya.

$$
\text { Untuk menetapkan pelaksanaan }
$$
pengembangan keprofesian berkelanjutan di sekolah, melalui jaringan sekolah, atau kepakaran lain, kepala sekolah perlu memperhatikan beberapa hal antara lain: a. tidak merugikan kepentingan belajar peserta didik b. sesuai dengan kebutuhan pengembangan profesionalisme guru dan peningkatan mutu sekolah c. kelayakan pelaksanaan program pengembangan keprofesian berkelanjutan ditinjau dari segi ketersediaan sumber daya manusia, biaya, dan waktu.

Diungkapkan Holbeche (2005) yang menjelaskan bahwa: organization need people to have the skills for the job. As jobs change, skills requirement alter. Although training and development are usually amongs the first area to be cut back in hard economics times, organization which maintain their investment in training and development such as (skills, leadership, innovation and teamworking) Dari pendapat diatas dapat diartikan bahwa organisasi membutuhkan orangorang yang mempunyai kemampuan dalam sebuah pekerjaan. Seperti perubahan kerja, kemampuan yang dibutuhkan selanjutnya. Termasuk didalamnya pelatihan dan pengembangan yang biasa menjadi sebuah factor penting dalam sebuah organisasi yang akan dapat menjaga nilai investasi dalam pengembangan dan pelatihan.

\section{PEMBAHASAN}

\section{Pengaruh Kepemimpinan pembelajaran Kepala Sekolah terhadap Kinerja Mengajar Guru}

Hasil pengujian hipotesis menunjukkan bahwa terdapat pengaruh yang positif dan signifikan antara kepemimpinan pembelajaran kepala sekolah terhadap mutu kinerja mengajar guru. Besarnya pengaruh kepemimpinan pembelajaran kepala sekolah terhadap mutu kinerja mengajar guru adalah 17,1\%, sisanya sebesar 82,9\% dipengaruhi oleh variabel lain.

Selanjutnya, dari perhitungan analisis regresi menunjukkan bahwa setiap penambahan satu poin, maka kinerja mengajar guru akan mengalami peningkatan sebesar 0,525 poin. Hal ini berarti bahwa semakin baik kepemimpinan pembelajaran kepala sekolah maka mutu kinerja mengajar guru akan semakin meningkat. Dengan demikian kepemimpinan pembelajaran kepala sekolah merupakan salah satu faktor yang memberikan pengaruh terhadap kinerja mengajar guru.

Kepemimpinan pembelajaran kepala sekolah berpengaruh terhadap mutu kinerja mengajar guru, disebabkan karena aktivitas kepala sekolah yang benar-benar memfokuskan diri terhadap peningkatan proses dan hasil belajar 
siswa melalui guru. Artinya kepemimpinan pembelajaran memberdayakan segenap kemampuan guru dalam mengajar sehingga kinerja mengajar guru meningkat. Kinerja mengajar guru yang bermutu pada gilirannya akan meningkatkan proses dan hasil belajar siswa karena hasil belajar siswa tidak langsung dari kepemimpinan pembelajaran kepala sekolah, melainkan melalui proses pengajaran yang dilakukan guru.

Hasil penelitian ini sejalan dengan temuan penelitian Cicih \& Endang (2015) yaitu seorang kepala sekolah dalam praktek kepemiminannya harus peningkatan mutu dan hasil pembelajaran yang komponen-komponennya terdiri daru kurikulum, kegiatan pembelajaran, penilaian/asesmen, upaya pemberdayaan dan pengembangan profesionalisme guru, peningkatan layanan pembelajaran, dan membangun komunitas belajar. Dengan demikian maka harus ada paradigma baru tentang praktek kepemimpinan kepala sekolah dasar yang harus lebih fokus pada peningkatan mutu dan hasil belajar.

\section{Pengaruh Pengembangan Keprofesian Berkelanjutan terhadap Mutu Kinerja Mengajar Guru}

Hasil pengujian hipotesis menunjukkan bahwa terdapat pengaruh yang positif dan signifikan antara pengembangan keprofesian berkelanjutan terhadap mutu kinerja mengajar guru. Besarnya pengaruh terhadap kinerja mengajar guru adalah 38,4\%, sisanya sebesar $61,6 \%$ dipengaruhi oleh variabel lain. Selanjutnya, perhitungan analisis regresi menunjukkan bahwa setiap penambahan satu poin akan mengalami peningkatan sebesar 0,610 poin., sehingga semakin tinggi pengembangan keprofesian berkelanjutan terhadap guru maka kinerja mengajar guru akan semakin meningkat. Dengan demikian, pengembangan keprofesian berkelanjutan merupakan salah satu faktor yang memberikan pengaruh terhadap kinerja mengajar guru.

Pengembangan profesi merupakan proses penyelenggaraan belajar dalam rangka meningkatkan penguasaan ilmu pengetahuan atau kemampuan manajemen beserta strategi penerapannya serta mampu meningkatkan kinerja yang lebih baik. (Komang. 2014)

Sejalan dengan hasil penelitian Ayu Dewi dkk (2017) bahwa pengembangan profesi guru adalah kegiatan guru dalam pengamalan ilmu dan pengetahuan, teknologi dan keterampilan untuk meningkatkan mutu, baik bagi proses belajar mengajar dan profesionalisme tenaga kependidikan lainnya.

Pengaruh Kepemimpinan Pembelajaran Kepala Sekolah dan Pengembangan keprofesian Berkelanjutan terhadap Mutu Kinerja Mengajar Guru

Hasil pengujian hipotesis menunjukkan bahwa terdapat pengaruh yang positif dengan signifikansi yang rendah antara kepemimpinan pembelajaran kepala sekolah dan pengembangan keprofesian berkelanjutan terhadap mutu kinerja mengajar guru. Besarnya pengaruh kepemimpinan pembelajaran kepala sekolah dan pengembangan keprofesian berkelanjutan terhadap mutu kinerja mengajar guru adalah 38,4\%, sisanya sebesar $61,6 \%$ dipengaruhi oleh variabel lain.

Selanjutnya, melalui perhitungan analisis regresi disimpulkan bahwa setiap penambahan satu poin kepeminpinan pembelajaran kepala sekolah dan pengembangan kprofesian berkelanjutani, maka mutu kinerja mengajar guru akan mengalami peningkatan sebesar 0,503 poin. Hal ini berarti semakin baik kepemimpinan pembelajaran kepala sekolah dan pengembangan keprofesian berkelanjutan terhadap mutu kinerja mengajar guru akan semakin meningkat. Dengan demikian, kepemimpinan pembelajaran kepala sekolah dan 
pengembangan keprofesian berkelanjutan merupakan salah satu faktor yang memberikan pengaruh terhadap kinerja mengajar guru.

Pengaruh yang sedang kepemimpinan pembelajaran kepala sekolah dan pengembangan keprofesian berkelanjutan terhadap mutu kinerja mengajar guru mengisyaratkan bahwa kedua variabel tersebut masih belum optimal berperan dalam meningkatkan mutu kinerja mengajar guru padahal sangat penting dalam menentukan kinerja mengajar guru. Hal ini disebabkan karena kepemimpinan pembelajaran kepala sekolah dan pengembangan keprofesian berkelanjutan terhadap mutu kinerja mengajar guru masih kurang tercurahkan waktu dan perhatiannya pada pelaksanaan kurikulum dan pengembangan guru.

Kepemimpinan pembelajaran kepala sekolah dan pengembangan keprofesian berkelanjutan terhadap mutu kinerja mengajar guru. Berdasarkan ulasan Hallinger dan Heck
(1993)

Pengaruh

kepemimpinan

pembelajaran (instructional leadership) terhadap peningkatan hasil belajar siswa sudah tidak diragukan lagi. Sejumlah ahli pendidikan telah melakukan penelitian tentang pengaruh kepemimpinan pembelajaran terhadap peningkatan hasil belajar. Mereka menyimpulkan peningkatan hasil belajar siswa sangat dipengaruhi oleh kepemimpinan pembelajaran.

Hasil penelitian yang dilakukan oleh Althauser (2015) mendukung penelitian ini menjelaskan bahwa program pengembangan keprofesian dapat meningkatkan pemberdayaan diri guru dan prestasi siswa. Pemberdayaan diri guru secara pribadi dan umum melalui partisipasi pada program pengembangan keprofesian memiliki hubungan untuk meningkatkan prestasi siswa sesuai dengan tujuan dari pengembangan keprofesian adalah untuk meningkatkan prestasi siswa.

\section{SIMPULAN}

Mutu Kinerja Mengajar Guru SD Negeri Di Kecamatan Batujajar Kabupaten Bandung Barat secara umum menunjukkan kriteria tinggi dengan penafsiran baik, secara khusus belum maksimalnya dalam memberikan jaminan atau assurance yang sering digunakan untuk mengevaluasi kepuasan peserta didik yakni pengetahuan, kemampuan, kesopanan, dan sifat dapat dipercaya mutu kinerja mengajar guru yang dimilikinya.

Kepemimpinan pembelajaran kepala sekolah SD Negeri Di Kecamatan Batujajar Kabupaten Bandung Barat secara umum menunjukkan kriteria tinggi dengan penafsiran baik, sedangkan secara khusus menunjukkan bahwa peranan kepala sekolah sebagai pemimpin pembelajaran dalam membimbing pengembangan proses belajar mengajar melalui penerapan kepemimpinan visioner dan situasional terhadap guru masih belum maksimal dirasakan.

Kepemimpinan pembelajaran kepala sekolah SD Negeri Di Kecamatan Batujajar Kabupaten Bandung Barat secara umum menunjukkan kriteria tinggi dengan penafsiran baik, sedangkan secara khusus menunjukkan bahwa peranan kepala sekolah sebagai pemimpin pembelajaran dalam membimbing pengembangan proses belajar mengajar melalui penerapan kepemimpinan visioner dan situasional terhadap guru masih belum maksimal dirasakan.

Terdapat pengaruh yang positif dan signifikan antara kepemimpinan pembelajaran kepala sekolah terhadap mutu kinerja mengajar guru, semakin baik kepemimpinan pembelajaran kepala sekolah maka mutu kinerja mengajar guru 
akan semakin meningkat. Dengan demikian kepemimpinan pembelajaran kepala sekolah merupakan salah satu faktor yang memberikan pengaruh terhadap kinerja mengajar guru. Kepemimpinan pembelajaran memberdayakan segenap kemampuan guru dalam mengajar sehingga kinerja mengajar guru meningkat. Kinerja mengajar guru yang bermutu pada gilirannya akan meningkatkan proses dan hasil belajar siswa karena hasil belajar siswa tidak langsung dari kepemimpinan pembelajaran kepala sekolah, melainkan melalui proses pengajaran yang dilakukan guru.

Terdapat pengaruh yang positif dan signifikan antara pengembangan keprofesian berkelanjutan terhadap mutu kinerja mengajar guru, sehingga semakin tinggi pengembangan keprofesian berkelanjutan terhadap guru maka kinerja mengajar guru akan semakin meningkat. Dengan demikian, pengembangan keprofesian berkelanjutan merupakan salah satu faktor yang memberikan pengaruh terhadap mutu kinerja mengajar guru.

Terdapat pengaruh yang positif dengan signifikansi yang rendah antara kepemimpinan pembelajaran kepala sekolah dan pengembangan keprofesian berkelanjutan terhadap mutu kinerja mengajar guru, maka mutu kinerja mengajar guru akan mengalami peningkatan. Semakin baik kepemimpinan pembelajaran kepala sekolah dan pengembangan keprofesian berkelanjutan terhadap mutu kinerja mengajar guru akan semakin meningkat. Dengan demikian, kepemimpinan pembelajaran kepala sekolah dan pengembangan keprofesian berkelanjutan merupakan salah satu faktor yang memberikan pengaruh terhadap kinerja mengajar guru.

\section{Implikasi}

Implikasi dari hasil penelitian ini didasarkan pada hasil kesimpulan pengaruh kepemimpinan pembelajaran kepala sekolah dan pengembangan keprofesian berkelanjutan guru terhadap mutu kinerja mengajar guru SD Negeri Di Kecamatan Batujajar Kabupaten Bandung Barat adalah sebagai berikut:

Masih belum maksimalnya kinerja mengajar guru dalam jaminan atau assurance yang digunakan untuk mengevaluasi kepuasan peserta didik yakni pengetahuan, kemampuan, kesopanan, dan sifat dapat dipercaya akan mengakibatkan keragu-raguan dari pihak pelanggan dalam hal ini peserta didik kuhusnya umumnya masyarakat sehingga dalam rangka meningkatkan mutu pendidikan akan mengalami hambatan.

Belum maksimalnya kepala sekolah dalam menjalankan perannya sebagai pemimpin pembelajaran, terutama dalam menerapkan pemimpin visioner dan situasional terhadap guru. Maka yang terjadi adalah: akan mengalami kesulitan untuk melakukan pembinaan dan pengembangan terhadap mutu kinerja mengajar guru karena menjadi dasar adalah diketahui kekuatan dan kelemahan melalui pelaksanaan evaluasi secara periodik dalam mengevaluasi mutu kinerja mengajar guru.

Pengembangan keprofesian berkelanjutan guru belum maksimal. Maka yang terjadi adalah: tidak akan terpenuhi mutu kinerja mengajar guru sebagai agen perubahan dan sumber belajar utama bagi peserta didik yang diharapkan dapat memberikan sumbangan yang sangat besar dalam peningkatan kualitas pendidikan.

Kepala sekolah yang belum maksimal memfokuskan terhadap perannya sebagai pemimpin pembelajaran, kinerja mengajar dalam proses pembelajaran gurupun tidak akan maksimal begitu pula hasil belajar peserta didik tidak akan meningkat

Guru yang belum memaksimalkan dalam melakukan pengembangan keprofesian baik oleh 
sendiri, teman sejawat dalam lingkungan sekolah sendiri, jaringan sekolah dan kepakaran, maka akan ketingggalan dalam pengembangan profesinya sehingga akan menimbulkan kejenuhan, susah dalam menentukan arah lebihlebih akan meurunnya mutu pendidikan.

Pengaruh yang sedang kepemimpinan pembelajaran kepala sekolah dan pengembangan keprofesian berkelanjutan terhadap mutu kinerja mengajar guru mengisyaratkan bahwa kedua variabel tersebut berakibat kurang optimalnya peran dalam meningkatkan mutu kinerja mengajar maka akan mempengaruhi kualitas pendidikan yan diharapkan.

\section{REKOMENDASI}

\begin{abstract}
Berdasarkan hasil penelitian yang diperoleh dari lapangan. Peneliti ingin mengemukakan beberapa rekomendasi yang bermanfaat bagi kemajuan guru SD Negeri Di
\end{abstract} Kecamatan Batujajar Kabupaten Bandung Barat.

Pada kenyataanya terdapat banyak faktor atau variabel yang dapat mempengaruhi mutu kinerja mengajar guru di samping kepemimpinan pembelajaran kepala sekolah dan pengembangan keprofesian berekelanjutan. Dalam penelitian selanjutnya perlu diungkup faktor-faktor lain yang berpengaruh secara langsung terhadap mutu kinerja mengajar guru. Disamping itu, perlu dilakukan penelitian atau pengembangan program kegiatan kepemimpinan pembelajaran kepala sekolah dan pengembangan keprofesian berekelanjutan yang secara langsung dapat meningkatkan mutu kinerja mengajar guru dan yang mampu menciptakan guru profesional sebagai agen perubahan dan sumber belajar utama bagi peserta didik dan menjadi sumbangan yang dalam peningkatan mutu pendidikan.

Dalam penelitian ini nilai kepemimpinan pembelajaran kepala sekolah yang masih rendah adalah dimensi kultur pembelajaran oleh karena itu kepemimpinan pembelajaran kepala sekolah harus benar-benar membuat perencanaan yang matang terutama menentukan kegiatan mengevaluasi secara perodik mutu kinerja guru sehingga mengetahui berbagai kekuatan dan kelemahan untuk meningkatkan mutu kinerja mengajar guru maka pemimipin yang demikian memahami akan arah dan tujuan dari suatu proses, dapat memenuhi harapan pelanggan dalam hal ini siswa melalui aktivitas kinerja mengajar guru yang bermutu sehingga terjadi perubahan ke yang lebih baik. Kepemimpinan visioner Menurut Komariah dan Triatna (2010:81-82) meliputi: Kemampuan dalam menentukan arah organisasi; Memahami keinginan masyarakat atau konsumen; Berpengaruh dalam aktivitas dan menjadi pemandu; dan Mampu mengantisipasi masa depan/sebagai agen perubahan.

$$
\text { Untuk pengembangan keprofesian }
$$
berkelanjutan guru yang masih rendah adalah dimensi kefakaran, maka dapat menggunakan sumber-sumber PKB selain kedua sumber PKB tersebut, yakni sumber kepakaran luar lainnya. Sumber kepakaran lain ini dapat disediakan melalui kegiatan di LPMP, P4TK, Perguruan Tinggi atau institusi layanan lain yang diakui oleh pemerintah ataupun melalui pendidikan dan pelatihan jarak jauh melalui jejaring virtual atau TIK yang diselenggarakan oleh institusi layanan luar negeri.

Kepada para peneliti selanjutnya disarankan: (1) untuk mengadakan penelitian terkait masalah mutu kinerja mengajar guru dengan 
menggunakan pendekatan kualitatif, sehingga akan dapat digali lebih mendalam hal-hal yang berkaitan dengan variabel tersebut, (2) untuk melakukan penelitian yang serupa (kuantitatif) ditinjau dari faktor-faktor lain selain variabel yang dikaji pada penelitian ini.

Kepada para pembuat kebijakan pendidikan di pemerintahan untuk mewujudkan misi perbaikan mutu pendidikan melalui upaya meningkatkan mutu kinerja mengajar guru, diharapkan memiliki perencanaan program yang lebih jelas dan disosialisasikan serta tindak lanjutnya secara nyata, agar tujuan yang direncanakan dapat tercapai.

Untuk mendapatkan hasil penelitian yang objektif, maka penelitian harus menekankan aspek kejujuran. Diharapkan dari sisi peneliti maupun responden dapat memberikan informasi atau data yang sesuai dengan keadaan yang sebenarnya.

\section{DAFTAR PUSTAKA}

Althauser, K. (2015). "Job-embedded professional development: its impact on teacher self-efficacy and student performance". Dalam Teacher Development: An International journal of teachers' professional development. [Online], Vol 19 (2), halaman 210-225. Tersedia.

Ayu. Dewi dkk. (2017) Pengembangan Profesi Guru Dalam Meningkatkan Kinerja Guru Jurnal Pendidikan Manajemen Perkantoran Vol.1 no.1 hal. 94-103 Juli 2017.UPI.

Bafadal, I. 2016. Peningkatan Mutu Pendidikan Melalui Kepemimpinan Pembelajaran. Materi Talk Show.

Cicih, Endang (2015) “Kepemimpinan Instruksional Kepala Sekolah, Komitmen Guru dan Mutu Kinerja Mengajar Guru”, Jurnal Administrasi Pendidikan Vol.XXII. No.1. April 2015.

Daryanto. (2011). Kepala Sekolah Sebagai Pemimpin Pembelajaran. Yogyakarta : Gava Media.

Farida, Dedy. (2015)"Kompetensi Kerja Guru, Kepemimpinan Pembelajaran dan Kinerja Mengajar Guru TK Kota Bandung”. Jurnal Administrasi Pendidikan Voll.xxii No.2. Oktober 2015.

Gorton, R.A. \& Schneider, G.T. 1991. Schools Based Leadership: Chalengge and Oppurtunities. Debuque, lowa:Wim C Brown Company Publisher.

Gorton, R.A. \& Schneider, G.T. 1991. Schools Based Leadership: Chalengge and Oppurtunities. Debuque, lowa:Wim C Brown Company Publisher.
Hallinger, P., \& Leitwood, K. (1994). Introduction: Exploring the Impact to Principal Leadership. School Effectiveness and School Improvement: An International Journal of Research, Policy, and Practice. 5 (3): 206-218.

Hamzah B. Uno. (2011). Teori Motivasi dan Pengukurannya: Analisis di Bidang Pendidikan. Jakarta: Bumi aksara

Hasibuan, J.J. dan Moedjiono. 2000. Proses Belajar Mengajar, Bandung: Remaja Rosdakarya.

Holbeche. (2005). The High Performance Organization. London: Elseiver Butterworth Heinemann.

Holbeche. (2005). The High Performance Organization. London: Elseiver Butterworth Heinemann

Komang, (2014). Pengaruh Pengembangan profesi, Iklim Sekolah, dan Kepemimpinan Kepala Sekolah Terhadap Kinerja Guru Di SMA Negeri 1 Abiansemal Tahun 2013. Volume 4 Tahun 2014

Komariah, A. \& Triana, C. (2010). Visionary leadership menuju sekolah efektif. Jakarta : Bumi Aksara

Lupiyoadi , Rambat. (2001). Manajemen Pemasaran Jasa. Jakarta : PT. Salemba Empat.

Matachi. (2006) Cavacity Building Fromework. UNESCO-II CBA. Addis Ababa: United Nations Economic Commission For Africa.

Matachi. (2006) Cavacity Building Fromework. UNESCO-II CBA. Addis Ababa: United Nations Economic Commission For Africa. 
McEwan E.K, (2002). 7 Step To effective Intructional Leadership. California:Corwin Press.

McEwan E.K, 2002. 7 Step To effective Intructional Leadership. California:Corwin Press.

Ngalim Purwanto, M. (1991)Administrasi dan Supervisi Pendidikan. Bandung: PT. Remaja Rosdakarya, , 26-27

Pemerintah Indonesia. Undang-Undang Nomor 20 Tahun 2003 Tentang Sistem Penidikan Nasional

Pemerintah Republik Indonesia. Kepala Badan Pengembangan Sumber Daya Manusia Pendidikan dan Penjaminan Mutu Pendidikan,2010; 3).

Pemerintah Republik Indonesia. Undang-Undang Nomor 14 Tahun 2005 Tentang Jabatan Fungsional Guru dan Angka Kredit.

Purwanto. (2010). Evaluasi Hasil Belajar. Yogyakarta: Pustaka Pelajar.

Rahman. (2005). Peran Strategis Kepala Sekolah dalam Meningkatkan Mutu Pendidikan. Alqaprint Jatinangor bekerjasama dengan Asosiasi Kepala Sekolah Indonesia (AKSI) : Bandung.

Sandu. S. (2015). Dasar Metodologi Penelitian, Yogyakarta: Literasi Media Publishing

Sergiovanni, T.J. (1991). The Principalship: $A$ Reflective Practice Perspective. Boston: Allyn and Bacon.
Soutworth, G. 2002. Intructional Leadership in School: Reflection and empical Evidence. School Leadeship and Management,

Sugiyono. (2010). Metode Penelitian Pendidikan Pendekatan Kuantitatif, kualitatif, dan $R \& D$. Bandung: Alfabeta.

Sugiyono. (2012). Metode Penelitian Kuantitatif Kualitatif dan R\&D. Bandung: Alfabeta.

Sugiyono. 2014. Metode Penelitian Pendidikan Pendekatan Kuantitatif, Kualitatif Dan $R \& D$. Bandung: Alfabeta.

Suhardan. D. (2014). Supervisi Profesional. (Layanan Dalam Meningkatkan Mutu Pengajaran di Era Otonomi Daerah). Bandung: Alfabeta.

Supardi. (2013). Kinerja Guru. Jakarta: PT Raja Grafindo Persada.

Supardi. 2013. Kinerja Guru. PT Raja Grafindo Persada, Jakarta.

Surya. (2003). Psikologi Pembelajaran dan Pengajaran. Bandung: Pustaka Bani Quraisy.

Ubben, G.C., \& Hughes, L.W. 1992. The Principal: Creative Leadership for Effective School. Boston: Allyn and Bacon, Inc. Prestasi.

Usman. H \& Raharjo. N.E. (2013) Strategi Kepemimpinan Pembelajaran Menyomgsong Implementasi Kurikulum 2013. Jurnal Cakrawala Pendidkan. Th.XXXII (1), hlm. 1-13 